Review

\title{
Fishing for "16 Psyche"
}

\author{
Relly Victoria Virgil Petrescu
}

ARoTMM-IFToMM, Bucharest Polytechnic University, Bucharest, (CE) Romania

\author{
Article history \\ Received: 20-07-2020 \\ Revised: 07-09-2020 \\ Accepted: 09-09-2020 \\ Email: rvvpetrescu@gmail.com
}

Abstract: 16 Psyche is one of the most massive asteroids in the asteroid belt. This object has a diameter of over $200 \mathrm{~km}$ and contains about $1 \%$ of the mass of the entire asteroid belt. It is believed to be the exposed iron core of a protoplanet and is the most massive metallic M-type asteroid. It was discovered by the Italian astronomer Annibale de Gasparis on March 17, 1852, in Naples and named after the Greek mythological figure Psyche. The prefix "16" means that it was the sixteenth minor planet in the order of discovery. 16 Psyche is the most massive metallic asteroid of type M. Radar observations indicate a fair pure iron-nickel composition. For a long time, scientists have imagined the possibility of fishing for metals from asteroids, or meteorites, close to our planet. Today, those predictions may come true. NASA is going to build a robot, called "Psyche", which will have the mission to explore an asteroid in the main asteroid belt between Mars and Jupiter. The asteroid "16 Psyche" has a diameter of 226 kilometers and is made of metals such as iron, nickel and gold. The metals that make up this unique asteroid could be worth more than \$10 trillion. Radar observations indicate that Psyche has a dense and mostly metallic composition, consistent with one of the highest radar albedos in the asteroid belt $(0.37 \pm 0.09)$. The psyche appears to have a surface that is $90 \%$ metallic and $10 \%$ silicate rock, with $6 \pm 1 \%$ orthopyroxene. Scientists believe that these metals can be mostly iron and nickel. NASA's infrared telescope installation at Mauna Kea Observatories reported evidence ( $\sim 3 \mu \mathrm{m}$ absorption characteristics) of hydroxyl ions on the asteroid in October 2016 that could suggest water ice. Because the psyche is believed to have formed in dry conditions without the presence of water, hydroxyl could have reached the psyche through previous impacts of lowcarbon asteroids. The psyche appears to be an exposed metal core or a fragment of a metal core in a larger differentiated parent body, about 500 kilometers in diameter. If the Psyche is really one, there could be other asteroids in similar orbits. However, Psyche is not part of any identified asteroid family. One hypothesis is that the collision that formed the Psyche occurred very early in the history of the Solar System and all other remains were transformed into fragments by subsequent collisions or had their orbits beyond recognition. However, this scenario is considered to have a probability of only $1 \%$. An alternative is that the psyche has been broken by impacts, but not catastrophically. In this case, it may be a candidate for the parent body of mesoseiderites (a class of meteorites with stony stones). Another possibility is that the Psyche is the end of the various relic bodies left by the formation of the inner planet. The asteroid's mantle may have been stripped not of a single collision, but of multiple (>3) relatively slow side collisions with bodies of comparable or larger size. What is left is a metal core covered by a thin layer of silicates, which is revealed spectrally. In such a case, the Psyche would be analogous to Mercury, but much less massive.

Keywords: NASA, 16 Psyche, Asteroid, Resources 


\section{Introduction}

Extraterrestrial life (or life in outer space) is a hypothesis that in the Universe there could be life whose natural environment is not Earth. This concept refers to any type or form of life, from the simplest biological systems (e.g., viruses and prokaryotes) to the most complex life forms with their own intelligence and social organization.

However, the existence of life outside the Earth would have been $95 \%$ proven in 2013 by a team of British researchers from the Department of Molecular Biology and Biotechnology at the University of Sheffield (Sagan, 1985).

The age of the Universe, huge, as well as the enormous number of stellar systems, suggest that if the Earth were a model of celestial bodies with generally valid life, then extraterrestrial life should be encountered in the Universe quite often. There is also an obvious contradiction between the probability of the existence of extraterrestrial civilizations in the Universe, probability estimated to be small but real and the lack of contacts with such civilizations or other evidence of their existence, a contradiction called Fermi's paradox.

The stars are too hot to house life phenomena. But because the Milky Way alone probably contains billions of planets, scientists assume that extraterrestrial life exists. As of August 1, 2014, more than 1,800 exoplanets had already been discovered, but all of them are too far from Earth and therefore too difficult to investigate for the existence of life forms.

Minimum conditions for the existence of life on an alien planet are:

- Energy (present for example through the relatively hot phenomena on Enceladus)

- Molecules containing carbon (organic substances), the water

Many of the planets already discovered or suspected orbit a binary or multiple solar systems; in these cases, their trajectories are very complicated geometric curves, which approach and depart from the respective Suns at large. That is why on these planets there are large variations in temperature, which practically exclude the existence of life. In other words, an additional condition is that the planet revolves around a single central star (as is the case with the Earth around the Sun).

Within our solar system are known several celestial bodies that meet the minimum conditions necessary for the appearance of life:

- Enceladus - a satellite of the planet Saturn

- Mars

- Europe - a satellite of the planet Jupiter

- Titan - a satellite of the planet Saturn
On November 26, 2011, the US space agency NASA launched the Mars Science Laboratory (MSL) space mission to Mars, whose main purpose is to investigate in detail whether life exists or has existed there.

There are several methane lakes on Titan. This is the simplest organic compound. Methane has been thought to be produced artificially by man (or possibly by another intelligent being) or naturally by fermenting plant or animal waste - see also methanogenesis. In reality, hydrocarbons exist throughout the universe in very large quantities and their genesis seems to have other origins (Petrescu, 2020).

The first contact between humanity and an alien civilization may be beneficial, but it will most likely be dangerous, shocking and result in our destruction. Astrobiology Professor Charles Cockell of the University of Edinburgh believes that autotrophic beings are generally not intelligent. This is because collecting sunlight (stellar) is a great way to gather energy, yet never gather enough energy for a creature to become intelligent. This means that an extraterrestrial being that has reached interstellar travel technology must necessarily be a predator: Only the consumption of other beings can provide the energy needed for a highly developed brain. Charles Cockell believes that it is not obligatory as a civilization, just because it can travel through space, it should also be altruistic. Mankind, for example, has successfully placed spacecraft on the frozen Titan satellite and yet we have wars and murders every day. Technological progress does not go hand in hand with altruism and a supposed extraterrestrial civilization may be quite dangerous. Stephen Hawking agrees, believing that we should be afraid of aliens, who are likely to come to Earth in search of resources and be put to our destruction. After the Mantell Case, historian David Michael Jacobs concludes about the UFO phenomenon: "They could be not only aliens but also potentially hostile to us."

Physicist Michio Kaku of City College in New York believes that Hollywood has "washed" people's brains with movies in which extraterrestrial superior forces are defeated by the underdeveloped resistance of the Earth, a kind of titanic battle between David and Goliath. He thinks more than likely that some kind of fight will break out between Bambi and Godzilla.

American astronomer Seth Shostak does not believe that these scenarios in the movies are plausible, it would make no sense for an advanced civilization to come to Earth in search of resources or to do an unauthorized reproduction experiment. This is because space travel is expensive and requires a huge investment and they would use very advanced robotic cars instead of coming themselves. The resources they would need and produce on their own or find closer to their mother planet.

Albert Harrison, professor emeritus of psychology at the University of California, Davis, believed that a very advanced civilization could teach mankind things like a 
theory of all things in physics, how to use zero-point energy or how to travel faster than light.

Even if an ancient and advanced extraterrestrial civilization wanted to help humanity, humans could have suffered a loss of identity and trust due to the technological and cultural development of extraterrestrial civilization. However, a friendly civilization can calibrate its contact with humanity so as to minimize unwanted consequences. Michael AG Michaud suggests that a friendly and advanced extraterrestrial civilization can even avoid any contact with an emerging intelligent species, such as humanity, to ensure that less advanced civilization can develop naturally at its own pace. known as the zoo hypothesis.

Physicists classify hypothetical extraterrestrial civilizations into three classes:

- $\quad$ Type I - extraterrestrial civilizations that would use all the energy resources of the planet on which they appeared. These civilizations, for example, exploit volcanoes and hurricanes

- Type II - which would use 10 billion times more energy than type I - by capturing it from the parent star. These civilizations exploit the stars

- Type III - which would use the energy of entire galaxies

On this scale, humanity has long remained of the "zero" type; that's why she can be instantly annihilated at the first contact, concludes Michio Kaku (Alien life, From Wikipedia).

SETI is an acronym for Search for Extra-Terrestrial Intelligence. It is about searching the cosmos for signals that could come from developed, intelligent extraterrestrial civilizations. There is also an international research institute in this field, called SETI Institute. SETI uses radio telescopes to search for narrowband bandwidth radio signals. These signals are not known to occur naturally, therefore their detection can provide evidence of extraterrestrial technology.

In the Solar System, even if there were primitive extraterrestrial life, intelligent extraterrestrial life does not exist. It must be sought in much larger areas of the cosmos.

Since 1960, several scientific programs have been launched to search for it, including searches for signals in the field of radio in the spectrum of electromagnetic waves.

For interstellar travel, which is so common in science fiction novels, it is far too early for mankind, the difficulties of such a journey are still invincible, the main cause being the overwhelming distances between Earth and other planets (exoplanets) and time necessary, corresponding to the distance.

Instead, astronomers are already researching the sky with radio telescopes, hoping that one day they will receive signals from a civilization on a distant planet, somewhere in the universe. This hope requires that distant civilization in turn have systems for the production and transmission of radio signals over long distances. In addition, it is necessary for that civilization to be in a stage of development and social organization somewhat appropriate to ours, so there is a need for a coincidence in time, which is also very unlikely.

However, even the research conducted here on Earth is not simple, again because of the vast expanses of the universe and galaxies. Our galaxy, the Milky Way alone, contains over 100 billion stars and has a diameter of about 100,000 light-years. Other galaxies contain even more distant stars. A small percentage of these stars could have planets with life-friendly physical conditions. However, in order to find a still totally unknown signal, coming from somewhere in the cosmos, it is undoubtedly necessary techniques, but also very sophisticated search strategies. To this day (2011) it is still not possible to even estimate the number of possible civilizations in the Milky Way with which human civilization could come into contact in the future. In addition, it is not possible to appreciate how long the search will take: Decades, millennia, or maybe even millions of years?

Planetary reserves are beginning to run out as consumption grows rapidly, with the development of planetary economies and the growth of our planet's population. For this reason, the problem of finding new planetary resources was desperately raised. A more normal method of resolving this anticipated crisis would be the conquest of outer space by mankind followed by our extension into outer space, but today we are a little behind with these desires, the necessary programs being only in the early stages. It is quite difficult to quickly build a strong, fast stellar fleet, able to ensure our extension in outer space when money is spent primarily on a small part of the population of the extremely rich planet that still wants to be even richer, for pointless arming, or on many useless projects. Medicine, the development of humanity, the greening of the planet we live on so that we can maintain it, our expansion as humanity, are less important desires for the great concerns and therefore also for the vast majority of the world's politicians. In the current conditions, it was necessary to endure several major planetary crises, followed by land wars, which automatically led to the depletion of the planet's population and a momentary slowdown in growth, which they also partially achieved and by the various pandemic. Fortunately, today the planet's energy problem is much better managed, primarily due to better management of classical resources, which in this way has enough time to recover (Petrescu, 2020).

A major improvement in the energy situation of the planet has occurred in large part due to new energy developed, nuclear, wind, solar, tidal, geothermal, bio, cogeneration... Today, when the fusion nuclear energy, clean energy indefinitely, it is almost ready to be achieved 
on an industrial scale, we are a little calmer in terms of energy. In addition, energy is already obtained from hydrogen by various methods and hydrogen is already obtained by decomposing water, by new methods, which require less energy to perform this process, methods reminiscent of photovoltaic processes performed by plants.

Clothing and footwear, as well as various materials, are produced today from oil and gas, given that oil is regenerating, as well as natural gas, which in addition have been discovered in massive additional quantities at great depths and today are already extracted through modern technologies.

Medicine takes precedence, without waiting for major sponsorships and today many diseases considered incurable in the past can be cured by modern methods. As an alternative method of support, recycling of metals, wood and paper, plastic, sometimes the glass is practiced all over the planet and this is a very good job that must continue much longer, based on the principle, "we used them, I no longer throw them to pollute nature but I recycle and thus save on raw materials" (Sagan, 1985; Rulkov et al., 2016; Agarwala, 2016; Babayemi, 2016; Gusti, 2016; Mohamed et al., 2016; Wessels and Raad, 2016; Rajput et al., 2016; Rea and Ottaviano, 2016; Zurfi and Zhang, 2016a; 2016b; Zheng and Li, 2016; Buonomano et al., 2016a; 2016b; Faizal et al., 2016; Ascione et al., 2016; Elmeddahi et al., 2016; Calise et al., 2016; Morse et al., 2016; Abouobaida, 2016; Rohit and Dixit, 2016; Kazakov et al., 2016; Alwetaishi, 2016; Riccio et al., 2016a; 2016b; Iqbal, 2016; Hasan and ElNaas, 2016; Al-Hasan and Al-Ghamdi, 2016; Jiang et al., 2016; Sepúlveda, 2016; Martins et al., 2016; Pisello et al., 2016; Jarahi, 2016; Mondal et al., 2016; Mansour, 2016; Al Qadi et al., 2016b; Campo et al., 2016; Samantaray et al., 2016; Malomar et al., 2016; Rich and Badar, 2016; Hirun, 2016; Bucinell, 2016; Nabilou, 2016; Barone et al., 2016; Chisari and Bedon, 2016; Bedon and Louter, 2016; dos Santos and Bedon, 2016; Minghini et al., 2016; Bedon, 2016; Jafari et al., 2016; Chiozzi et al., 2016; Orlando and Benvenuti, 2016; Wang and Yagi, 2016; Obaiys et al., 2016; Ahmed et al., 2016; Jauhari et al., 2016; Syahrullah and Sinaga, 2016; Shanmugam, 2016; Jaber and Bicker, 2016; Wang et al., 2016; Moubarek and Gharsallah, 2016; Amani, 2016; Shruti, 2016; Pérez-de León et al., 2016; Mohseni and Tsavdaridis, 2016; Abu-Lebdeh et al., 2016; Serebrennikov et al., 2016; Budak et al., 2016; Augustine et al., 2016; Jarahi and Seifilaleh, 2016; Nabilou et al., 2016; You et al., 2016; AL Qadi et al., 2016a; Rama et al., 2016; Sallami et al., 2016; Huang et al., 2016; Ali et al., 2016; Kamble and Kumar, 2016; Saikia and Karak, 2016; Zeferino et al., 2016; Pravettoni et al., 2016; Bedon and Amadio, 2016; Chen and $\mathrm{Xu}, 2016$; Mavukkandy et al., 2016; Yeargin et al., 2016; Madani and Dababneh, 2016; Alhasanat et al., 2016; Elliott et al., 2016; Suarez et al., 2016; Kuli et al., 2016; Waters et al., 2016; Montgomery et al., 2016;
Lamarre et al., 2016; Petrescu, 2012b; Aversa et al., 2017a; 2017b; 2016a; 2016b; 2016c; 2016d; 2016e; 2016f; 2016g; 2016h; 2016i; 2016j; 2016k; 20161; 2016m; 2016n; 2016o; Petrescu and Petrescu, 2016; 2015a; 2015b; 2015c; 2015d; 2015e; 2014a; 2014b; 2014c; 2014d; 2014e; 2014f; 2014g; 2014h; 2014i; 2013a; 2013b; 2013c; 2013d; 2013e; 2013f; 2013g; 2012; 2011; 2005a; 2005b; 2005c; 2005d; 2005e; 2003; 2002a; 2002b; 2000a; 2000b; 1997a; 1997b; 1997c; 1995a; 1995b; Petrescu, 2018; 2015a; 2015b; 2012a; Petrescu et al., 2016; 2017a; 2017b; 2017c; 2017d; 2018a; 2018b; 2018c; 2018d; Petrescu and Calautit, 2016a; 2016b; Daud et al., 2008; Taher et al., 2008; Zulkifli et al., 2008; Pourmahmoud, 2008; Pannirselvam et al., 2008; $\mathrm{Ng}$ et al., 2008; El-Tous, 2008; Akhesmeh et al., 2008; Nachiengtai et al., 2008; Moezi et al., 2008; Boucetta, 2008; Darabi et al., 2008; Semin and Bakar, 2008; AlAbbas, 2009; Abdullah et al., 2009; Abu-Ein, 2009; Opafunso et al., 2009; Semin et al., 2009a; 2009b; 2009c; Zulkifli et al., 2009; Ab-Rahman et al., 2009; Abdullah and Halim, 2009; Zotos and Costopoulos, 2009; Feraga et al., 2009; Bakar et al., 2009; Cardu et al., 2009; Bolonkin, 2009a; 2009b; Nandhakumar et al., 2009; Odeh et al., 2009; Lubis et al., 2009; Fathallah and Bakar, 2009; Marghany and Hashim, 2009; Kwon et al., 2010; Aly and Abuelnasr, 2010; Farahani et al., 2010; Ahmed et al., 2010; Kunanoppadon, 2010; Helmy and ElTaweel, 2010; Qutbodin, 2010; Pattanasethanon, 2010; Fen et al., 2011; Thongwan et al., 2011; Theansuwan et al., 2011; Al Smadi, 2011; Tourab et al., 2011; Raptis et al., 2011; Momani et al., 2011; Ismail et al., 2011; Anizan et al., 2011; Tsolakis and Raptis, 2011; Abdullah et al., 2011; Kechiche et al., 2011; Ho et al., 2011; Rajbhandari et al., 2011; Aleksic and Lovric, 2011; Kaewnai and Wongwises, 2011; Darwazeh and Ahmed, 2011; Ebrahim et al., 2012; Abdelkrim et al., 2012; Mohan et al., 2012; Abam et al., 2012; Hassan et al., 2012; Jalil and Sampe, 2013; Jaoude and El-Tawil, 2013; Ali and Shumaker, 2013; Zhao, 2013; El-Labban et al., 2013; Djalel et al., 2013; Nahas and Kozaitis, 2014).

\section{Materials and Methods}

A major problem that still plagues our planet is the massive need for metals, heavy, light, special, rare, precious, alloys, which are increasingly needed, while planetary surface resources are increasingly limited.

Given the declining planetary resources and increasing their consumption, at least some of them could be brought from outside the planet, such as metals or diamonds, so as not we try to find them or supplements in the depths of the earth, so as not to disturb the balance of our planet.

The attempt to dig deeper into the earth's crust, embarking on a journey to the depths, in search of new metals and other deposits, has failed, being even more 
difficult today than a journey through outer space, an underwater, one in space, or one to a nano size world. For this reason, scientists have recently remembered about an older idea of trying to bring metals from outer space, where they exist in massive quantities, especially since some sources (asteroids) are quite close and today we already have very fast ships capable to realizes of such a brave and daring enterprise.

Astronomers created icon-like symbols for the first fifteen asteroids to be discovered, as a type of shorthand notation consistent with older notation for the classical planets. Psyche was given an iconic symbol, as were a few other asteroids discovered after 16 Psyche. The symbol 16 Psyche, a semicircle topped by a star, represents a butterfly's wing, a symbol of the soul (psyche is the Greek word for "soul") and a star.

However, the iconic symbols for all asteroids were superseded and Psyche's symbol never came into use. With more than a dozen asteroids discovered, remembering all their individual emblems became increasingly unwieldy and in 1851, German astronomer J.F. Encke suggested using a circled number instead. The first new asteroid that was designated in 1852 using this new scheme was 16 Psyche when American astronomer James Ferguson published his observations.

Psyche (Fig. 1), is massive enough that its gravitational perturbations on other asteroids can be observed, which enables a mass measurement. The values for the mass of $3.38 \pm 0.28 \times 10^{-11} \mathrm{M}_{\odot}$ and the density of $6.98 \pm 0.58 \mathrm{~g} / \mathrm{cm}^{3}$ obtained from a 2002 analysis by Kuzmanoski and Kovačević, of a close encounter with asteroid (13206) 1997 GC22. The new, high-density estimate suggests that 16 Psyche must be composed mostly of metals. As of 2019, the best mass estimate is $(2.41 \pm 0.32) \times 10^{19} \mathrm{~kg}$, with a derived bulk density of $(3.99 \pm 0.26) \mathrm{g} / \mathrm{cm}^{3}$.

The first size estimate of Psyche came from IRAS thermal infrared emission observations. They showed that it had a diameter of about $253 \mathrm{~km}$, although it was likely an overestimate as Psyche was viewed pole-on at that time. Light curve analysis indicates Psyche appears somewhat irregular in shape. There is a pronounced mass deficit near the equator at about $90^{\circ}$ longitude comparable to the Rheasilvia basin on Vesta. There are also two additional smaller $(50-70 \mathrm{~km}$ in diameter) crater-like depressions near the south pole. Psyche's north pole points towards the ecliptic coordinates $\beta=28^{\circ}, \lambda=-6^{\circ}$, with a $4^{\circ}$ uncertainty. This gives an axial tilt of $95^{\circ}$.

Observations of two multi-chord stellar occultations of 2010 and 2014 allow the matching of light curve inversions DAMIT model 1806 that give an equivalentvolume mean diameter of $216 \pm 12 \mathrm{~km}$ and an equivalent surface means the diameter of $227 \pm 13 \mathrm{~km}$. The density of Psyche derived from these estimates $-3.7 \pm 0.6 \mathrm{~g} / \mathrm{cm}^{3}$ is consistent with that of other metallic asteroids.

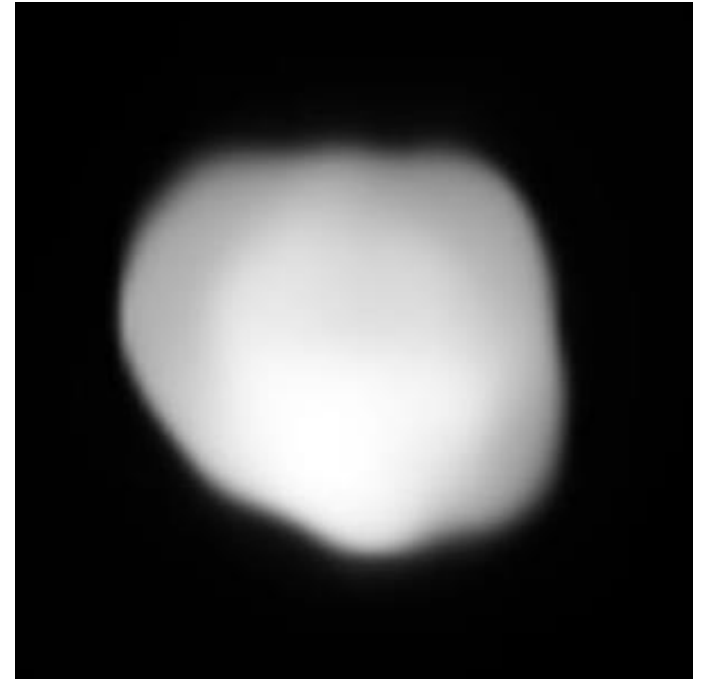

Fig. 1: 16 Psyche imaged by the Very Large Telescope's adaptive optics SPHERE imager

Observations of Psyche with Very Large Telescope's adaptive optics SPHERE imager revealed two large craters, which were informally named Meroe and Panthia, after the twin witches in the Roman novel Metamorphoses by Apuleius.

NASA is going to build a robot, called "Psyche", which will have the mission to explore an asteroid in the main asteroid belt between Mars and Jupiter. The asteroid "16 Psyche" has a diameter of 226 kilometers and is made of metals such as iron, nickel and gold. The metals that make up this unique asteroid could be worth more than \$ 10 trillion.

Located in the main asteroid belt between Mars and Jupiter, "16 Psyche" is rich in metals including iron, nickel and the core is made of gold.

Researchers believe that the asteroid's core is similar to that of Earth, which means it could be the heart of a dead planet that has lost its rocky outer layers or suffered violent collisions. The metals that make up this asteroid could be worth $\$ 10$ trillion.

The "Psyche" robot is scheduled to be launched in 2022, using a SpaceX Falcon Heavy rocket. A year later, in 2023, it will pass over the planet Mars and only in 2026 will it orbit the asteroid "16 Psyche".

The "Psyche" mission is part of NASA's low-cost robotic space mission program.

The team must now build the three scientific tools that the robot will be equipped with:

- A magnetometer to measure the asteroid's magnetic field

- A multispectral imager to capture images of the asteroid's surface

Spectrometers that analyze neutrons and gamma rays coming from the surface to reveal what the asteroid is made of. 
The assembly and testing of the robotic spacecraft begin in February 2021. The mission will also test NASA's new laser communications technology, called "Deep Space Optical Communications".

\section{Results and Discussion}

The reserves of natural gas and even the oil reserves of our planet are preserved and restored periodically, or rather they are refreshed from somewhere in the depths of the planet, a fact already established and confirmed by scientists. At a rational use of them, ie at a normal operation, the natural reserves of hydrocarbons are permanently restored. However, today we are also able to produce hydrocarbons in unlimited quantities not only by chemical reactions but also by nuclear or other reactions, directly from air or water, or from other planetary resources, the energy cost being quite reasonable. The problem now is one of ethics, if it is still ethical to produce and burn hydrocarbons when in fact it would be more normal to try to eliminate hydrocarbons from atmospheric air introduced by man through pollution in the last 160 years since we burned oil and natural gas. Today we have sufficient energy resources, nuclear, wind, solar, geothermal, from tides or waves and others, so that the continued use of hydrocarbon resources would be a great hoax for mankind because major pollution to the atmosphere, water and land, it would be far too large and the imbalances would add many other negative consequences on the planet's climate and life on earth, which is already hampered by pollution and overpopulation of the planet with declining basic resources. On the other hand, many of the products obtained today from oil and/or gas were made in the past from plants or other non-polluting natural raw materials. Let's just think about polluting the planet's waters with plastic bottles and bags dumped into the planet's waters, which eventually end up in seas and oceans and severely pollute planetary waters with serious consequences for our ecosystem, including fish and aquatic animals.

It would probably be time to think a lot more about what we do and how we do it if we love the planet we live on, especially since we don't even have a spare one at the moment.

Radar observations indicate that Psyche has a dense and mostly metallic composition, consistent with one of the highest radar albedos in the asteroid belt $(0.37 \pm 0.09)$. The psyche appears to have a surface that is $90 \%$ metallic and $10 \%$ silicate rock, with $6 \pm 1 \%$ orthopyroxene. Scientists believe that these metals can be mostly iron and nickel.

NASA's infrared telescope installation at Mauna Kea Observatories reported evidence $(\sim 3 \mu \mathrm{m}$ absorption characteristics) of hydroxyl ions on the asteroid in October 2016 that could suggest water ice. Because the psyche is believed to have formed in dry conditions without the presence of water, hydroxyl could have reached the psyche through previous impacts of low-carbon asteroids.

The psyche appears to be an exposed metal core or a fragment of a metal core in a larger differentiated parent body, about 500 kilometers in diameter. If the Psyche is really one, there could be other asteroids in similar orbits. However, Psyche is not part of any identified asteroid family. One hypothesis is that the collision that formed the Psyche occurred very early in the history of the Solar System and all other remains were transformed into fragments by subsequent collisions or had their orbits beyond recognition. However, this scenario is considered to have a probability of only $1 \%$. An alternative is that the psyche has been broken by impacts, but not catastrophically. In this case, it may be a candidate for the parent body of mesoseiderites (a class of meteorites with stony stones).

Another possibility is that the Psyche is the end of the various relic bodies left by the formation of the inner planet. The asteroid's mantle may have been stripped not of a single collision, but of multiple (>3) relatively slow side collisions with bodies of comparable or larger size. What is left is a metal core covered by a thin layer of silicates, which is revealed spectrally. In such a case, the Psyche would be analogous to Mercury, but much less massive.

No spacecraft has visited Psyche, but in 2014 a mission to Psyche was proposed to NASA. A team led by Lindy Elkins-Tanton, director of the Arizona State University School of Earth and Space Exploration, presented a concept for a robotic psychic orbiter. This team claimed that 16 The Psyche will be a valuable object for the study, as it is the only body similar to the metal core discovered so far.

The spacecraft would orbit the Psyche for 20 months, studying topography, surface features, gravity, magnetism and other features and would rely on current technology, avoiding high costs and the need to develop new technologies. On September 30, 2015, the dizzying psychic mission was one of the five semifinalist proposals of the Discovery Program.

The mission was approved by NASA on January 4, 2017 and was originally intended to launch in October 2023 , with a gravitational assistance maneuver of the Earth in 2024, a roof of Mars in 2025 and which reached the asteroid in 2030. In May 2017, the launch date has shifted to a more efficient trajectory, launching in 2022, with gravitational assistance to Mars in 2023 and reaching 2026.

On February 28, 2020, NASA awarded SpaceX a \$ 117 million contract to launch the Psyche spacecraft and two small side missions on a Falcon Heavy rocket in July 2022.

\section{Conclusion}

Given the declining planetary resources and increasing their consumption, at least some of them could be brought from outside the planet, such as metals 
or diamonds, so as not we try to find them or supplements in the depths of the earth, so as not to disturb the balance of our planet.

NASA is going to build a robot, called "Psyche", which will have the mission to explore an asteroid in the main asteroid belt between Mars and Jupiter. The asteroid "16 Psyche" has a diameter of 226 kilometers and is made of metals such as iron, nickel and gold. The metals that make up this unique asteroid could be worth more than $\$ 10$ trillion.

Located in the main asteroid belt between Mars and Jupiter, "16 Psyche" is rich in metals including iron, nickel and the core is made of gold.

Researchers believe that the asteroid's core is similar to that of Earth, which means it could be the heart of a dead planet that has lost its rocky outer layers or suffered violent collisions. The metals that make up this asteroid could be worth $\$ 10$ trillion.

The "Psyche" robot is scheduled to be launched in 2022, using a SpaceX Falcon Heavy rocket. A year later, in 2023, it will pass over the planet Mars and only in 2026 will it orbit the asteroid "16 Psyche".

The "Psyche" mission is part of NASA's low-cost robotic space mission program.

The team must now build the three scientific tools that the robot will be equipped with:

- A magnetometer to measure the asteroid's magnetic field

- A multispectral imager to capture images of the asteroid's surface

Spectrometers that analyze neutrons and gamma rays coming from the surface to reveal what the asteroid is made of. The assembly and testing of the robotic spacecraft begin in February 2021. The mission will also test NASA's new laser communications technology, called "Deep Space Optical Communications".

\section{Acknowledgement}

The work was appreciated by teams of professors from the departments of automobiles from several universities in Romania and Italy. This text was acknowledged and appreciated by Associate Professor Aniello Riccio seconda Universita' Degli Studi di Napoli Italy, whom we thanks and in this way.

\section{Funding Information}

Research contract: Contract number 36-5-4D/1986 from 24IV1985, beneficiary CNST RO (Romanian National Center for Science and Technology) Improving dynamic mechanisms internal combustion engines. All these matters are copyrighted. Copyrights: 548-cgiyw Dssin, from: 22-04-2010, 08:48:48.

\section{Ethics}

Author declares that are not ethical issues that may arise after the publication of this manuscript. This article is original and contains unpublished material.

\section{References}

Ab-Rahman, M. S., Guna, H., Harun, M. H., Zan, S. D., \& Jumari, K. (2009). Cost-effective fabrication of selfmade $1 \times 12$ polymer optical fiber-based optical splitters for automotive application. Am. J. Eng. Applied Sci, 2, 252-259.

Abam, F. I., Ugot, I. U., \& Igbong, D. I. (2012). Performance analysis and components irreversiblities of a (25 MW) gas turbine power plant modeled with a spray cooler. American Journal of Engineering and Applied Sciences, 5(1), 35-41.

Abdelkrim, H., Othman, S. B., Salem, A. K. B., \& Saoud, S. B. (2012). Dynamic partial reconfiguration contribution on system on programmable chip architecture for motor drive implementation. Am. J. Eng. Applied Sci, 5, 15-24.

Abdullah, M. Z., Saat, A., \& Hamzah, Z. (2011). Optimization of energy dispersive $\mathrm{X}$-ray fluorescence spectrometer to analyze heavy metals in moss samples. American Journal of Engineering and Applied Sciences, 4(3).

Abdullah, M., A. F.M. Zain, Y. H. Ho and S. Abdullah, 2009. TEC and scintillation study of equatorial ionosphere: A month campaign over sipitang and parit raja stations, Malaysia. Am. J. Eng. Applied Sci., 2: 44-49. DOI: 10.3844/ajeassp.2009.44.49

Abdullah, H., \& Halim, S. A. (2009). Electrical and Magnetoresistive studies Nd doped on La-Ba-Mn-O sub (3) Manganites for Lowfield Sensor application. American Journal of Engineering and Applied Sciences, 2(2).

Abouobaida, H. (2016). Robust and efficient controller to design a standalone source supplied DC and AC load powered by photovoltaic generator. Am. J. Eng. Applied Sci, 9, 894-901.

Abu-Ein, S. (2009). Numerical and analytical study of exhaust gases flow in porous media with applications to diesel particulate filters. Am. J. Eng. Applied Sci, 2, 70-75.

Abu-Lebdeh, T. M., Leon, G. P. D., Hamoush, S. A., Seals, R. D., \& Lamberti, V. E. (2016). Gas atomization of molten metal: part II. Applications. American Journal of Engineering and Applied Sciences, 9(2).

Agarwala, S. (2016). A perspective on 3D bioprinting technology: Present and future. Am. J. Eng. Applied Sci, 9, 985-990. 
Ahmed, M., Khan, R., Billah, M., \& Farhana, S. (2010). A novel navigation algorithm for hexagonal hexapod robot. Am. J. Eng. Applied Sci, 3, 320-327.

Ahmed, R., Khan, M., Haque, H., \& Rahman, H. (2016). An approach to develop a dynamic job shop scheduling by fuzzy rule-based system and comparative study with the traditional priority rules. Am. J. Eng. Applied Sci, 9, 202-212.

Akhesmeh, S., Pourmahmoud, N., \& Sedgi, H. (2008). Numerical study of the temperature separation in the Ranque-Hilsch vortex tube. American Journal of Engineering and Applied Sciences, 1(3).

Al-Abbas, I. K. (2009). Reduced order models of a current source inverter induction motor drive. Am. J. Eng. Applied Sci, 2, 39-43.

Alien life. From Wikipedia, the free encyclopedia. https://ro.wikipedia.org/wiki/Via\%C8\%9B\%C4\%83 _extraterestr\%C4\%83

Al-Hasan, M. I., \& Al-Ghamdi, A. S. (2016). Energy balance for a diesel engine operates on a pure biodiesel, diesel fuel and biodiesel-diesel blends. Am. J. Eng. Applied Sci, 9, 458-465.

Al Smadi, T. A. (2011). Low cost smart sensor design. Am. J. Eng. Applied Sci, 4, 162-168.

Al Qadi, A. N. S., ALhasanat, M. B., Dahamsheh, A. A., \& Zaiydneen, S. A. (2016a). Using of boxbenken method to predict the compressive strength of selfcompacting concrete containing Wadi Musa bentonite, Jordan. Am. J. Eng. Applied Sci, 9, 406-411.

Al Qadi, A. N., Alhasanat, M. B., \& Haddad, M. (2016b). Effect of crumb rubber as coarse and fine aggregates on the properties of asphalt concrete. Am. J. Eng. Applied Sci, 9, 558-564.

Aleksic, S., \& Lovric, A. (2011). Energy consumption and environmental implications of wired access networks. Am. J. Eng. Applied Sci, 4, 531-539.

Alhasanat, M. B., Al Qadi, A. N., Al Khashman, O. A., \& Dahamsheh, A. (2016). Scanning electron microscopic evaluation of self-compacting concrete spalling at elevated temperatures. Am. J. Eng. Applied Sci, 9, 119-127.

Ali, K. S., \& Shumaker, J. L. (2013). Hardware in the loop simulator for multi agent unmanned aerial vehicles environment. American Journal of Engineering and Applied Sciences, 6(2), 172.

Ali, G. A. M., Fouad, O., \& Makhlouf, S. A. (2016). Electrical properties of cobalt oxide/silica nanocomposites obtained by sol-gel technique. Am. J. Eng. Applied Sci, 9, 12-16.

Alwetaishi, M. S. (2016). Impact of building function on thermal comfort: A review paper. Am. J. Eng. Applied Sci, 9, 928-945.

Aly, W. M., \& Abuelnasr, M. S. (2010). Electronic design automation using object oriented electronics. American Journal of Engineering and Applied Sciences, 3(1).
Amani, N. (2016). Design and implementation of optimum management system using cost evaluation and financial analysis for prevention of building failure. Am. J. Eng. Applied Sci, 9, 281-296.

Anizan, S., Yusri, K., Leong, C. S., Amin, N., Zaidi, S., \& Sopian, K. (2011). Effects of the contact resistivity variations of the screen-printed silicon solar cell. Am. J. Eng. Applied Sci, 4, 328-331.

Ascione, F., Bianco, N., De Masi, R. F., De Rossi, F., De Stasio, C., \& Vanoli, G. P. (2016). Energy audit of health care facilities: Dynamic simulation of energy performances and energy-oriented refurbishment of system and equipment for microclimatic control.

Augustine, A., Prakash, R. D., Xavier, R., \& Parassery, M. C. (2016). Review of signal processing techniques for detection of power quality events. Am. J. Eng. Applied Sci, 9, 364-370.

Aversa, R., Petrescu, R. V., Apicella, A., \& Petrescu, F. I. (2017a). Nano-diamond hybrid materials for structural biomedical application. American Journal of Biochemistry and Biotechnology, 13(1), 34-41.

Aversa, R., Parcesepe, D., Petrescu, R. V., Berto, F., Chen, G., Petrescu, F. I., ... \& Apicella, A. (2017b). Processability of bulk metallic glasses. American Journal of Applied Sciences, 14(2), 294-301.

Aversa, R., Petrescu, F. I., Petrescu, R. V., \& Apicella, A. (2016a). Biomimetic finite element analysis bone modeling for customized hybrid biological prostheses development. American Journal of Applied Sciences, 13(11), 1060-1067.

Aversa, R., Parcesepe, D., Petrescu, R. V. V., Chen, G., Petrescu, F. I. T., Tamburrino, F., \& Apicella, A. (2016b). Glassy amorphous metal injection molded induced morphological defects.

Aversa, R., Petrescu, R. V., Petrescu, F. I., \& Apicella, A. (2016c). Smart-factory: Optimization and process control of composite centrifuged pipes. American Journal of Applied Sciences, 13(11), 1330-1341.

Aversa, R., Tamburrino, F., Petrescu, R. V., Petrescu, F. I., Artur, M., Chen, G., \& Apicella, A. (2016d). Biomechanically inspired shape memory effect machines driven by muscle like acting NiTi alloys. American Journal of Applied Sciences, 13(11), 1264-1271.

Aversa, R., Buzea, E. M., Petrescu, R. V., Apicella, A., Neacsa, M., \& Petrescu, F. I. (2016e). Present a mechatronic system having able to determine the concentration of carotenoids. American Journal of Engineering and Applied Sciences, 9(4), 1106-1111.

Aversa, R., Petrescu, R. V., Sorrentino, R., Petrescu, F. I., \& Apicella, A. (2016f). Hybrid ceramo-polymeric nanocomposite for biomimetic scaffolds design and preparation. American Journal of Engineering and Applied Sciences, 9(4). 
Aversa, R., Perrotta, V., Petrescu, R. V., Carlo, M., Petrescu, F. I., \& Apicella, A. (2016g). From structural colors to super-hydrophobicity and achromatic transparent protective coatings: Ion plating plasma assisted TiO 2 and SiO 2 nano-film deposition. Available at SSRN 3074477.

Aversa, R., Petrescu, R. V., Petrescu, F. I., \& Apicella, A. (2016h). Biomimetic and evolutionary design driven innovation in sustainable products development. American Journal of Engineering and Applied Sciences, 9(4).

Aversa, R., Petrescu, R. V., Apicella, A., \& Petrescu, F. I. (2016i). Mitochondria are naturally micro robots-a review. American Journal of Engineering and Applied Sciences, 9(4).

Aversa, R., Petrescu, R. V., Apicella, A., \& Petrescu, F. I. (2016j). Mitochondria are naturally micro robots-a review. American Journal of Engineering and Applied Sciences, 9(4).

Aversa, R., Petrescu, R. V., Apicella, A., \& Petrescu, F. I. (2016k). Physiologic human fluids and swelling behavior of hydrophilic biocompatible hybrid ceramo-polymeric materials. American Journal of Engineering and Applied Sciences, 9(4), 962-972.

Aversa, R., Petrescu, R. V., Apicella, A., \& Petrescu, F. I. (20161). One can slow down the aging through antioxidants. American Journal of Engineering and Applied Sciences, 9(4).

Aversa, R., Petrescu, R. V., Apicella, A., \& Petrescu, F. I. (2016m). About homeopathy or $\ll$ Similia similibus curentur $\gg$. American Journal of Engineering and Applied Sciences, 9(4).

Aversa, R., Petrescu, R. V., Apicella, A., \& Petrescu, F. I. (2016n). The basic elements of life's. American Journal of Engineering and Applied Sciences, 9(4), 1189-1197.

Aversa, R., Petrescu, F. I., Petrescu, R. V., \& Apicella, A. (2016o). Flexible stem trabecular prostheses. American Journal of Engineering and Applied Sciences, 9(4).

Babayemi, A. K. (2016). Thermodynamics, non-linear isotherms, statistical modeling and optimization of phosphorus adsorption from wastewater. Am. J. Eng. Applied Sci, 9, 1019-1026.

Bakar, R. A., Mohammed, M. K., \& Rahman, M. M. (2009). Numerical study on the performance characteristics of hydrogen fueled port injection internal combustion engine. Am. J. Eng. Applied Sci, 2, 407-415.

Barone, G., Buonomano, A., Forzano, C., \& Palombo, A. (2016). WLHP systems in commercial buildings: A case study analysis based on a dynamic simulation approach. Am. J. Eng. Applied Sci, 9, 659-668.
Bedon, C. (2016). Review on the use of FRP composites for facades and building skins.

Bedon, C., \& Amadio, C. (2016). A unified approach for the shear buckling design of structural glass walls with non-ideal restraints. Am. J. Eng. Applied Sci, 9, 64-78.

Bedon, C., \& Louter, C. (2016). Finite-element numerical simulation of the bending performance of post-tensioned structural glass beams with adhesively bonded cfrp tendons.

Bolonkin, A. (2009a). Femtotechnology: Nuclear matter with fantastic properties. Am. J. Eng. Applied Sci, 2(2), 501-514.

Bolonkin, A. A. (2009b). Converting of matter to nuclear energy by ab-generator. Am. J. Eng. Applied Sci, 2, 683-693.

Boucetta, A. (2008). Vector control of a variable reluctance machine stator and rotor discs imbricates. American Journal of Engineering and Applied Sciences, 1(4).

Bucinell, R. B. (2016). Stochastic model for variable amplitude fatigue induced delamination growth in graphite/epoxy laminates. Am. J. Eng. Applied Sci, 9, 635-646.

Budak, S., Xiao, Z., Johnson, B., Cole, J., Drabo, M., Tramble, A., \& Casselberry, C. (2016). High Efficient Advanced Thermoelectric Devices from Different Multilayer Thin Films.

Buonomano, A., Calise, F., \& Vicidomini, M. (2016a). A novel prototype of a small-scale solar power plant: Dynamic simulation and thermoeconomic analysis. Am. J. Eng. Applied Sci, 9, 770-788.

Buonomano, A., Calise, F., d'Accadia, M. D., Vanoli, R., \& Vicidomini, M. (2016b). Simulation and experimental analysis of a demonstrative solar heating and cooling plant installed in Naples (Italy). Am. J. Eng. Applied Sci, 9, 798-813.

Calise, F., Dâ'Accadia, M. D., Libertini, L., Quiriti, E., \& Vicidomini, M. (2016). Dynamic simulation and optimum operation strategy of a trigeneration system serving a hospital. Am. J. Eng. Applied Sci, 9, 854-867.

Campo, T., Cotto, M., Márquez, F., Elizalde, E., \& Morant, C. (2016). Graphene Synthesis by PlasmaEnhanced CVD Growth with Ethanol. American Journal of Engineering and Applied Sciences, 9(3).

Cardu, M., Oreste, P., \& Cicala, T. (2009). Analysis of the tunnel boring machine advancement on the Bologna-Florence railway link. Am. J. Eng. Applied Sci, 2, 416-420.

Chen, G., \& Xu, L. (2016). A general strategy to enhance up conversion luminescence in rare-earthion-doped oxide nanocrystals. Am. J. Eng. Applied Sci, 9, 79-83. 
Chiozzi, A., Milani, G., Grillanda, N., \& Tralli, A. (2016). An adaptive procedure for the limit analysis of FRP reinforced masonry vaults and applications.

Chisari, C., \& Bedon, C. (2016). Multi-objective optimization of FRP jackets for improving the seismic response of reinforced concrete frames.

Darabi, A., Soleamani, S. A., \& Hassannia, A. (2008). Fuzzy based digital automatic voltage regulator of a synchronous generator with unbalanced loads. American J. of Engineering and Applied Sciences, 1(4), 280-286.

Daud, H., Yahya, N., Aziz, A. A., \& Jusoh, M. F. (2008). Development of wireless electric concept powering electrical appliances. Am. J. Eng. Applied Sci, 1, 12-15.

dos Santos, F. A., \& Bedon, C. (2016). Preliminary experimental and finite-element numerical assessment of the structural performance of SMAreinforced GFRP systems. American Journal of Engineering and Applied Sciences, 9(3), 692-701.

Djalel, D., Mourad, M., \& Labar, H. (2013). New approach of electromagnetic fields of the lightning discharge. Am. J. Eng. Applied Sci, 6, 369-383.

Ebrahim, A.N., Ahmed, S., Abdul Rashid, S. H., \& Taha, Z. (2012). Technology use in the virtual R\&D teams. American Journal of Engineering and Applied Sciences, 5(1), 9-14.

El-Labban, H. F., Abdelaziz, M., \& Mahmoud, E. R. (2013). Modification of carbon steel by laser surface melting: Part I: Effect of laser beam travelling speed on microstructural features and surface hardness. Am. J. Eng. Applied Sci, 6, 352-359.

Elliott, A., AlSalihi, S., Merriman, A. L., \& Basti, M. M. (2016). Infiltration of nanoparticles into porous binder jet printed parts. American Journal of Engineering and Applied Sciences, 9(1).

Elmeddahi, Y., Mahmoudi, H., Issaadi, A., Goosen, M. F., \& Ragab, R. (2016). Evaluating the effects of climate change and variability on water resources: A case study of the cheliff Basin in Algeria. American Journal of Engineering and Applied Sciences, 9(4), 835-845.

El-Tous, Y. (2008). Pitch angle control of variable speed wind turbine. American Journal of Engineering and Applied Sciences, 1(2), 118-120.

Faizal, A., Mulyono, S., Yendra, R., \& Fudholi, A. (2016). Design Maximum Power Point Tracking (MPPT) on photovoltaic panels using fuzzy logic method. Am. J. Eng. Applied Sci, 9, 789-797.

Farahani, A. S., Adam, N. M., \& Ariffin, M. K. A. (2010). Simulation of airflow and aerodynamic forces acting on a rotating turbine ventilator. Am. J. Eng. Applied Sci, 3, 159-170.
Fathallah, A. Z. M., \& Bakar, R. A. (2009). Prediction studies for the performance of a single cylinder high speed spark ignition linier engine with spring mechanism as return cycle. American Journal of Engineering and Applied Sciences, 2(4).

Fen, Y. W., Yunus, W. M. M., \& Yusof, N. A. (2011). Optical properties of cross-linked chitosan thin film for copper ion detection using surface plasmon resonance technique. Opt. Appl., 41(4), 999-1013.

Feraga, C. E., Moussaoui, A., Bouldjedri, A., \& Yousfi, A. (2009). Robust position controller for a permanent magnet synchronous actuator. American Journal of Engineering and Applied Sciences, 2(2).

Gusti, A. P. Semin, (2016). The effect of vessel speed on fuel consumption and exhaust gas emissions. Am. J. Eng. Applied Sci, 9, 1046-1053.

Hassan, M., Mahjoub, H., \& Obed, M. (2012). Voicebased control of a DC servo motor. American Journal of Engineering and Applied Sciences, 5(1).

Hasan, S., \& El-Naas, M. H. (2016). Optimization of a combined approach for the treatment of carbide slurry and capture of CO2. Am. J. Eng. Applied Sci, 9, 449-457.

Helmy, A. K., \& El-Taweel, G. S. (2010). Neural network change detection model for satellite images using textural and spectral characteristics. American Journal of Engineering and Applied Sciences, 3(4).

Hirun, W. (2016). Evaluation of interregional freight generation modelling methods by using nationwide commodity flow survey data. Am. J. Eng. Applied Sci, 9, 625-634.

Ho, C. Y. F., Ling, B. W. K., Giovanni, B. S., Chi, Z. W., \& Siu, W. C. (2011). Single step optimal block matched motion estimation with motion vectors having arbitrary pixel precisions. In 2010 7th International Symposium on Communication Systems, Networks \& Digital Signal Processing (CSNDSP 2010) (pp. 316-326). IEEE.

Huang, B., Masood, S. H., Nikzad, M., Venugopal, P. R., \& Arivazhagan, A. (2016). Dynamic mechanical properties of fused deposition modelling processed polyphenylsulfone material. Am. J. Eng. Applied Sci, 9, 1-11.

Darwazeh, I., \& Ahmed, S., (2011). Inverse discrete Fourier transform-discrete Fourier transform techniques for generating and receiving spectrally efficient frequency division multiplexing signals. American Journal of Engineering and Applied Sciences, 4, 598-606.

Iqbal, M. (2016). An overview of Energy Loss Reduction (ELR) software used in Pakistan by WAPDA for calculating transformer overloading, line losses and energy losses. Am. J. Eng. Applied Sci, 9, 442-448. 
Ismail, M. I. S., Okamoto, Y., Okada, A., \& Uno, Y. (2011). Experimental investigation on microwelding of thin stainless steel sheet by fiber laser. Am. J. Eng. Applied Sci, 4, 314-320.

Jaber, A. A., \& Bicker, R. (2016). Industrial robot fault detection based on statistical control chart. Am. J. Eng. Applied Sci, 9, 251-263.

Jafari, N., Alsadoon, A., Withana, C. P., Beg, A., \& Elchouemi, A. (2016). Designing a comprehensive security framework for smartphones and mobile devices. American Journal of Engineering and Applied Sciences, 9(3), 724-734.

Jalil, M. I. A. \& Sampe, J. (2013). Experimental investigation of thermoelectric generator modules with different technique of cooling system. American Journal of Engineering and Applied Sciences, 6(1), 1-7.

Jaoude, A. A. \& El-Tawil, K. (2013). Analytic and nonlinear prognostic for vehicle suspension systems. American Journal of Engineering and Applied Sciences, 6(1), 42-56.

Jarahi, H. (2016). Probabilistic seismic hazard deaggregation for Karaj City (Iran). Am. J. Eng. Applied Sci, 9, 520-529.

Jarahi, H., \& Seifilaleh, S. (2016). Rock fall hazard zonation in Haraz Highway. Am. J. Eng. Applied Sci, 9, 371-379.

Jauhari, K., Widodo, A., \& Haryanto, I. (2016). Identification of a machine tool spindle critical frequency through modal and imbalance response analysis. Am. J. Eng. Applied Sci, 9, 213-221.

Jiang, J., Chen, Q., \& Nimbalkar, S. (2016). Field data based method for predicting long-term settlements.

Kaewnai, S., \& Wongwises, S. (2011). Improvement of the runner design of francis turbine using computational fluid dynamics. Am. J. Eng. Applied Sci, 4, 540-547.

Kamble, V. G., \& Kumar, N. (2016). Fabrication and tensile property analysis of polymer matrix composites of graphite and silicon carbide as fillers. Am. J. Eng. Applied Sci, 9, 17-30.

Kazakov, V. V., Pavlikov, A. I., Kamensky, V. A., Yusupov, V. I., \& Bagratashvili, V. N. (2016). Control of bubble formation at the optical fiber tip by analyzing ultrasound acoustic waves. American Journal of Engineering and Applied Sciences, 9(4), 921-927.

Kechiche, O. B. H. B., Sethom, H. B. A., Sammoud, H., \& Belkhodja, I. S. (2011). Optimized high frequency signal injection based permanent magnet synchronous motor rotor position estimation applied to washing machines. American Journal of Engineering and Applied Sciences, 4(3).

Kuli, I., Abu-Lebdeh, T. M., Fini, E. H., \& Hamoush, S. A. (2016). The use of nano-silica for improving mechanical properties of hardened cement paste. Am. J. Eng. Applied Sci, 9, 146-154.
Kunanoppadon, J. (2010). Thermal efficiency of a combined turbocharger set with gasoline engine. Am. J. Eng. Applied Sci, 3, 342-349.

Kwon, S., Tani, Y., Okubo, H., \& Shimomura, T. (2010). Fixed-star tracking attitude control of spacecraft using single-gimbal control moment gyros. Am. J. Eng. Applied Sci, 3, 49-55.

Lamarre, A., Fini, E. H., \& Abu-Lebdeh, T. M. (2016). Investigating effects of water conditioning on the adhesion properties of crack sealant. Am. J. Eng. Applied Sci, 9, 178-186.

Lubis, Z., Abdalla, A. N., Mortaza, M., \& Ghon, R. (2009). Mathematical Modeling of the Three Phase Induction Motor Couple to DC Motor in Hybrid Electric Vehicle. American Journal of Engineering and Applied Sciences, 2(4).

Madani, D.A.L. \& Dababneh, A. (2016). Rapid entire body assessment: A literature review. American Journal of Engineering and Applied Sciences, 9(1), 107-118.

Malomar, G. E., Gueye, A., Mbow, C., Traore, V. B., \& Beye, A. C. (2016). Numerical study of natural convection in a square porous cavity thermally modulated on both side walls. Am. J. Eng. Applied Sci, 9, 591-598.

Mansour, M. A. (2016). Developing an anthropometric database for Saudi students and comparing Saudi dimensions relative to Turkish and Iranian peoples. American Journal of Engineering and Applied Sciences, 9(3), 547-557.

Marghany, M., \& Hashim, M. (2009). Robust of doppler centroid for mapping sea surface current by using radar satellite data. Am. J. Eng. Applied Sci, 2, 781-788.

Martins, F. R., Gonçalves, A. R., \& Pereira, E. B. (2016). Observational study of wind shear in northeastern Brazil. Am. J. Eng. Applied Sci, 9, 484-504.

Mavukkandy, M. O., Chakraborty, S., Abbasi, T., \& Abbasi, S. A. (2016). A clean-green synthesis of platinum nanoparticles utilizing a pernicious weed lantana (Lantana Camara). Am. J. Eng. Applied Sci, 9, 84-90.

Minghini, F., Tullini, N., \& Ascione, F. (2016). Updating Italian design guide CNR DT-205/2007 in view of recent research findings: Requirements for pultruded FRP profiles.

Moezi, N., Dideban, D., \& Ketabi, A. (2008). A novel integrated SET based inverter for nano power electronic applications. Am. J. Eng. Applied Sci, 1, 219-222.

Mohamed, M. A., Tuama, A. Y., Makhtar, M., Awang, M. K., \& Mamat, M. (2016). The effect of RSA exponential key growth on the multi-core computational resource. Am. J. Eng. Applied Sci, 9, 1054-1061. 
Mohan, S. R. K., Jayabalan, P., \& Rajaraman, A. (2012). Properties of fly ash based coconut fiber composite. American Journal of Engineering and Applied Sciences, 5(1).

Mohseni, E., \& Tsavdaridis, K. D. (2016). Effect of nano-alumina on pore structure and durability of Class F Fly ash self-compacting mortar. American Journal of Engineering and Applied Sciences, 9(2), 323-333.

Momani, M. A., Al Smadi, T. A., Al Taweel, F. M., \& Ghaidan, K. A. (2011). GPS ionospheric total electron content and scintillation measurements during the October 2003 magnetic storm. Am. J. Eng. Applied Sci, 4, 301-306.

Mondal, R., Sahoo, S., \& Rout, C. S. (2016). Mixed nickel cobalt manganese oxide nanorods for supercapacitor application.

Montgomery, J., Abu-Lebdeh, T. M., Hamoush, S. A., \& Picornell, M. (2016). Effect of nano-silica on the compressive strength of harden cement paste at different stages of hydration. Am. J. Eng. Applied Sci, 9, 166-177.

Morse, A., Mansfield, M. M., Alley, R. M., Kerr, H. A., \& Bucinell, R. B. (2016). Traction enhancing products affect maximum torque at the shoe-floor interface: A potential increased risk of ACL injury. Am. J. Eng. Applied Sci, 9, 889-893.

Moubarek, T., \& Gharsallah, A. (2016). A six-port reflectometer calibration using Wilkinson power divider. Am. J. Eng. Applied Sci, 9, 274-280.

Nabilou, A. (2016). Effect of parameters of selection and replacement drilling bits based on geomechanical factors:(Case study: Gas and oil reservoir in the Southwest of Iran). Am. J. Eng. Applied Sci, 9, 380-395.

Nabilou, A., Carvalho, M. T., Dias, N., Brogueira, P., Salamunićcar, G., Loncaric, S., ... \& Gonçalves, M. C. (2016). Study of the parameters of Steam Assisted Gravity Drainage (SAGD) method for enhanced oil recovery in a heavy oil fractured carbonate reservoir. Am. J. Eng. Applied Sci, 9, 647-658.

Nachiengtai, T., Chim-Oye, W., Teachavorasinskun, S., \& Sa-Ngiamvibool, W. (2008). Identification of shear band using elastic shear wave propagation. American Journal of Engineering and Applied Sciences, 1(3).

Nahas, R., \& Kozaitis, S. P. (2014). Metric for the fusion of synthetic and real imagery from multimodal sensors. American Journal of Engineering and Applied Sciences, 7(4), 355.

Nandhakumar, S., Selladurai, V., \& Sekar, S. (2009). Numerical investigation of an industrial robot arm control problem using haar wavelet series. American Journal of Engineering and Applied Sciences, 2(4).
Ng, K. C., Yusoff, M. Z., Munisamy, K., Hasini, H., \& Shuaib, N. H. (2008). Time-marching method for computations of high-speed compressible flow on structured and unstructured grid. Am. J. Eng. Applied Sci, 1(2), 89-94.

Obaiys, S. J., Abbas, Z., Long, N. N., Ahmad, A. F., Ahmedov, A., \& Raad, H. K. (2016). On the general solution of first-kind hypersingular integral equations. Am. J. Eng. Applied Sci, 9, 195-201.

Odeh, S., Faqeh, R., Eid, L. A., \& Shamasneh, N. (2009). Vision-based obstacle avoidance of mobile robot using quantized spatial model. Am. J. Eng. Applied Sci, 2, 611-619.

Opafunso, Z. O., Ozigis, I. I., \& Adetunde, I. A. (2009). Pneumatic and hydraulic systems in coal fluidized bed combustor. Am. J. Eng. Applied Sci, 2, 88-95.

Orlando, N., \& Benvenuti, E. (2016). Advanced XFEM simulation of pull-out and debonding of steel bars and FRP-reinforcements in concrete beams. Am. J. Eng. Applied Sci, 9, 746-754.

Pannirselvam, N., Raghunath, P. N., \& Suguna, K. (2008). Neural network for performance of glass fibre reinforced polymer plated RC beams. Am. J. Eng. Applied Sci, 1(1), 82-88.

Pattanasethanon, S. (2010). The solar tracking system by using digital solar position sensor. American Journal of Engineering and Applied Sciences, 3(4), 678-682.

Pérez-de León, G., Lamberti, V. E., Seals, R. D., AbuLebdeh, T. M., \& Hamoush, S. A. (2016). Gas atomization of molten metal: Part I. Numerical modeling conception. American Journal of Engineering and Applied Sciences, 9(2).

Petrescu, F., \& Petrescu, R. (1995a). Contributions to optimization of the polynomial motion laws of the stick from the internal combustion engine distribution mechanism. Bucharest, 1, 249-256.

Petrescu, F., \& Petrescu, R. (1995b). Contributions to the synthesis of internal combustion engine distribution mechanisms. Bucharest, 1, 257-264.

Petrescu, F., \& Petrescu, R. (1997a). Dynamics of cam mechanisms (exemplified on the classic distribution mechanism). Bucharest, 3, 353-358.

Petrescu, F., \& Petrescu, R. (1997b). Contributions to the synthesis of the distribution mechanisms of internal combustion engines with a Cartesian coordinate method. Bucharest, 3, 359-364.

Petrescu, F., \& Petrescu, R. (1997c). Contributions to maximizing polynomial laws for the active stroke of the distribution mechanism from internal combustion engines. Bucharest, 3, 365-370.

Petrescu, F., \& Petrescu, R. (2000a). Synthesis of distribution mechanisms by the rectangular (Cartesian) coordinate method. University of Craiova, Craiova. 
Petrescu, F., \& Petrescu, R. (2000b). The design (synthesis) of cams using the polar coordinate method (triangle method). University of Craiova, Craiova.

Petrescu, F., \& Petrescu, R. (2002a). Motion laws for cams. In Proceedings of the International Computer Assisted Design, National Symposium with Participation, (SNP'02), Braşov (pp. 321-326).

Petrescu, F., \& Petrescu, R. (2002b). Dynamics of cam mechanisms. In Proceedings of the National Symposium with International Participation Computer Assisted Design, (CAD’02), Brasov (pp. 327-332).

Petrescu, F., \& Petrescu, R. (2003). Some elements regarding the improvement of the engine design. In Proceedings of the National Symposium, Descriptive Geometry, Technical Graphics and Design, (GTD'03), Braşov (pp. 353-358).

Petrescu, F. I., \& Petrescu, R. V. (2005a). The cam design for a better efficiency. Available at SSRN 3076805.

Petrescu, F. I., \& Petrescu, R. V. (2005b, September). Contributions at the Dynamic of Cams. In The Ninth IFTOMM International Symposium on Theory of Machines and Mechanisms.

Petrescu, F. I., \& Petrescu, R. V. (2005c). Determining the dynamic efficiency of cams. Available at SSRN 3076802 .

Petrescu, F. I., \& Petrescu, R. V. (2005d). An original internal combustion engine. In The Ninth IFTOMM International Symposium on Theory of Machines and Mechanisms.

Petrescu, R. V., \& Petrescu, F. I. (2005e). Determining the mechanical efficiency of Otto engine's mechanism. Available at SSRN 3076804.

Petrescu, R. V., \& Petrescu, F. I. (2013a). Lockheed Martin. Books on Demand GmbH, Norderstedt.

Petrescu, R.V., \& Petrescu, F. I. (2013b). Northrop. CreateSpace.

Petrescu, R. V., \& Petrescu, F. I. (2013c). The Aviation History or New Aircraft I Color.

Petrescu, F. I., \& Petrescu, R. V. (2013d). Forces and efficiency of cams. Int. Rev. Mech. Eng, 7(3), 507-511.

Petrescu, F. I., \& Petrescu, R. V. (2013e). Cams with high efficiency. Int. Rev. Mech. Eng, 7(4), 599-606.

Petrescu, F. I. T., \& Petrescu, R. V. (2013f). An algorithm for setting the dynamic parameters of the classic distribution mechanism. Int. Rev. Modell. Simulat, 6, 1637-1641.

Petrescu, F. I., \& Petrescu, R. V. (2013g). Dynamic synthesis of the rotary cam and translated tappet with roll. Engevista, 15(3).

Petrescu, F. I., \& Petrescu, R. V. (2012). New Aircraft II: Germany 2012. BoD-Books on Demand.
Petrescu, F. I., \& Petrescu, R. V. (2011). Memories about Flight!. Create Space Publisher.

Petrescu, F. I., \& Petrescu, R. V. (2014a). Parallel moving mechanical systems. Independent Journal of Management \& Production (IJM\&P), 5(3).

Petrescu, F. I., \& Petrescu, R. V. (2014b). Cam gears dynamics in the classic distribution. Independent Journal of Management \& Production (IJM\&P), 5(1).

Petrescu, F. I., \& Petrescu, R. V. (2014c). High efficiency gears synthesis by avoid the interferences. Independent Journal of Management \& Production (IJM\&P), 5(2).

Petrescu, F. I., \& Petrescu, R. V. (2014d). Gear design.

Petrescu, F. I., \& Petrescu, R. V. (2014e). KINETOSTATIC OF THE 3R DYAD. Engevista, 16(3), 314-321.

Petrescu, F. I. T., \& Petrescu, R. V. (2014f). Balancing otto engines. Int. Rev. Mech. Eng, 8, 473-480.

Petrescu, F. I. T., \& Petrescu, R. V. (2014g). Machine equations to the classical distribution. Int. Rev. Mech. Eng, 8, 309-316.

Petrescu, F. I. T., \& Petrescu, R. V. (2014h). Forces of internal combustion heat engines. Int. Rev. Modell. Simulat, 7, 206-212.

Petrescu, F. I. T., \& Petrescu, R. V. (2014i). Determination of the yield of internal combustion thermal engines. Int. Rev. Mech. Eng, 8, 62-67.

Petrescu, F. I., \& Petrescu, R. V. (2015a). Forces at the main mechanism of a railbound forging manipulator. Independent Journal of Management \& Production, 6(4).

Petrescu, F. I., \& Petrescu, R. V. (2015b). Kinematics at the main mechanism of a railbound forging manipulator. Independent Journal of Management \& Production, 6(3).

Petrescu, F. I. T., \& Petrescu, R. V. V. (2015c). Machine motion equations. Independent Journal of Management \& Production, 6(3), 773-802.

Petrescu, F. I., \& Petrescu, R. V. (2015d). Presenting a railbound forging manipulator. In Applied Mechanics and Materials (Vol. 762, pp. 219-224). Trans Tech Publications Ltd.

Petrescu, F. I., \& Petrescu, R. V. (2015e). Direct and inverse kinematics to the anthropomorphic robots.

Petrescu, F. I., \& Petrescu, R. V. (2016). An otto engine dynamic model. Independent Journal of Management \& Production (IJM\&P), 7(1).

Petrescu, F. I. T. (2018). About the nuclear particles' structure and dimensions. Computational Particle Mechanics, 6(2), 191-194.

Petrescu, F. I. (2015a). Geometrical synthesis of the distribution mechanisms. American Journal of Engineering and Applied Sciences, 8(1), 63-81.

Petrescu, F. I. T. (2015b). Machine motion equations at the internal combustion heat engines. American Journal of Engineering and Applied Sciences, 8(1), 127. 
Petrescu, F. I. T. (2012a). Particle annihilation-a source of renewable energy. Infinite Energy.

Petrescu, F. I., Apicella, A., Petrescu, R. V., Kozaitis, S., Bucinell, R., Aversa, R., \& Abu-Lebdeh, T. (2016). Environmental protection through nuclear energy. American Journal of Applied Sciences, 13(9), 941-946.

Petrescu, R. V., Aversa, R., Akash, B., Berto, F., Apicella, A., \& Petrescu, F. I. (2017a). Forces of a 3R robot. Journal of Mechatronics and Robotics, 1(1).

Petrescu, R. V., Aversa, R., Akash, B., Berto, F., Apicella, A., \& Petrescu, F. I. (2017b). Direct geometry.

and cinematic to the MP-3R systems. Journal of Mechatronics and Robotics, 1(1).

Petrescu, R. V., Aversa, R., Akash, B., Berto, F., Apicella, A., \& Petrescu, F. I. (2017c). Dynamic elements at MP3R. Journal of Mechatronics and Robotics, 1(2), 24-37.

Petrescu, R. V., Aversa, R., Akash, B., Berto, F., Apicella, A., \& Petrescu, F. I. (2017d). Geometry and direct kinematics to MP3R with $4 \times 4$ operators. Journal of Mechatronics and Robotics, 1(2), 38-46.

Petrescu, R. V., Aversa, R., Apicella, A., \& Petrescu, F. I. (2018a). Total static balancing and kinetostatics of the 3R base cinematic Chain. Journal of Mechatronics and Robotics, 2(1), 1-13.

Petrescu, R. V., Aversa, R., Apicella, A., \& Petrescu, F. I. (2018b). Switching from flat to spatial motion to 3R mechatronic systems. Journal of Mechatronics and Robotics, 2(1), 14-22.

Petrescu, R. V., Aversa, R., Apicella, A., \& Petrescu, F. I. (2018c). The dynamics of the planar cinematic balanced chain at the plan module 3R. Journal of Mechatronics and Robotics, 2(1), 23-34.

Petrescu, R. V., Aversa, R., Apicella, A., \& Petrescu, F. I. (2018d). Dynamic kinematics of the plan balanced chain at the planar module 3R. Journal of Mechatronics and Robotics, 2(1), 35-44.

Petrescu, F. I. (2020). Proper Management of Planetary Hydrocarbon Resources. Available at SSRN 3609509.

Petrescu, F. I., \& Calautit, J. K. (2016a). About nano fusion and dynamic fusion. American Journal of Applied Sciences, 13(3).

Petrescu, F. I., \& Calautit, J. K. (2016b). About the light dimensions. American Journal of Applied Sciences, 13(3).

Petrescu, F. I. T. (2012b). Particle annihilation-a source of renewable energy. Infinite Energy.

Pisello, A. L., Pignatta, G., Piselli, C., Castaldo, V. L., \& Cotana, F. (2016). Investigating the dynamic thermal behavior of building envelope in summer conditions by means of in-field continuous monitoring. Am. J. Eng. Applied Sci, 9, 505-519.
Pourmahmoud, N. (2008). Rarefied gas flow modeling inside rotating circular cylinder. Am. J. Eng. Applied Sci, 1(1), 62-65.

Pravettoni, M., Polo Lopez, C. S., \& Kenny, R. P. (2016). Impact of the edges of a backside diffusive reflector on the external quantum efficiency of luminescent solar concentrators: Experimental and computational approach. American Journal of Engineering and Applied Sciences, 9(1), 53-63.

Qutbodin, K. (2010). Merging autopilot/flight control and navigation-flight management systems. Am. J. Eng. Applied Sci, 3, 629-630.

Rajbhandari, S., Ghassemlooy, Z., \& Angelova, M. (2011). The performance of a dual header pulse position modulation in the presence of artificial light interferences in an indoor optical wireless communications channel with wavelet denoising. American Journal of Engineering and Applied Sciences, 4(4), 513-519.

Rajput, R. S., Pandey, S., \& Bhadauria, S. (2016). Correlation of biodiversity of algal genera with special reference to the waste water effluents from industries. Am. J. Eng. Applied Sci, 9, $1127-$ 1133.

Raptis, K. G., Papadopoulos, G. A., Costopoulos, T. N., \& Tsolakis, A. D. (2011). Experimental study of load sharing in roller-bearing contact by caustics and photoelasticity. Am. J. Eng. Applied Sci, 4, 294-300.

Rama, G., Marinković, D., \& Zehn, M. (2016). Efficient co-rotational 3-node shell element. American Journal of Engineering and Applied Sciences.

Rea, P., \& Ottaviano, E. (2016). Analysis and mechanical design solutions for sit-to-stand assisting devices. Am. J. Eng. Applied Sci, 9, 1134-1143.

Riccio, A., Caruso, U., Raimondo, A., \& Sellitto, A. (2016a). Robustness of XFEM method for the simulation of cracks propagation in fracture mechanics problems.

Riccio, A., Cristiano, R., \& Saputo, S. (2016b). A brief introduction to the bird strike numerical simulation.

Rich, F., \& Badar, M. A. (2016). Statistical analysis of auto dilution Vs manual dilution process in inductively coupled plasma spectrometer tests. Am. J. Eng. Applied Sci, 9, 611-624.

Rohit, K., \& Dixit, S. (2016). Mechanical properties of waste Biaxially Oriented Polypropylene metallized films (BOPP), LLDPE: LDPE films with sisal fibres. Am. J. Eng. Applied Sci, 9, 913-920.

Rulkov, N. F., Hunt, A. M., Rulkov, P. N., \& Maksimov, A. G. (2016). Quantization of mapbased neuronal model for embedded simulations of neurobiological networks in real-time. American Journal of Engineering and Applied Sciences, 9(4), 973-984. 
Sagan, C. (1985). Cosmos. Ballantine Books.

Saikia, A., \& Karak, N. (2016). Castor oil based epoxy/clay nanocomposite for advanced applications. Am. J. Eng. Applied Sci, 9, 31-40.

Sallami, A., Zanzouri, N., \& Ksouri, M. (2016). Robust diagnosis of a DC motor by bond graph approach. Am. J. Eng. Applied Sci, 9, 432-438.

Samantaray, K. S., Sahoo, S., \& Rout, C. S. (2016). Hydrothermal synthesis of CuWO4-reduced graphene oxide hybrids and supercapacitor application. Am. J. Eng. Applied Sci, 9, 584-590.

Semin, S., Ismail, A. R., \& Bakar, R. A. (2009a). Combustion temperature effect of diesel engine convert to compressed natural gas engine. American Journal of Engineering and Applied Sciences, 2(1).

Semin, Ismail, A. R., \& Rosli, A. B. (2009b). Effect of diesel engine converted to sequential port injection compressed natural gas engine on the cylinder pressure vs crank angle in variation engine speeds. Am J Eng and Applied Sci, 2(1), 154-9.

Semin, S., Ismail, A. R., \& Bakar, R. A. (2009c). Diesel engine convert to port injection $\mathrm{CNG}$ engine using gaseous injector nozzle multi holes geometries improvement: A review. American Journal of Engineering and Applied Sciences, 2(2).

Semin, R. A. B. (2008). A technical review of compressed natural gas as an alternative fuel for internal combustion engines. Am. J. Eng. Appl. Sci, $1(4), 302-311$.

Sepúlveda, J. A. M. (2016). Outlook of municipal solid waste in Bogota (Colombia). Am. J. Eng. Applied Sci, 9, 477-483.

Serebrennikov, A., Serebrennikov, D., \& Hakimov, Z. (2016). Polyethylene pipeline bending stresses at an installation. Am. J. Eng. Applied Sci, 9, 350-355.

Shanmugam, K. (2016). Flow dynamic behavior of fish oil/silver nitrate solution in mini-channel, effect of alkane addition on flow pattern and interfacial tension. Am. J. Eng. Applied Sci, 9, 236-250.

Shruti, (2016). Comparison in cover media under stegnography: Digital media by hide and seek approach. Am. J. Eng. Applied Sci, 9, 297-302.

Suarez, L., Abu-Lebdeh, T. M., Picornell, M., \& Hamoush, S. A. (2016). Investigating the role of fly ash and silica fume in the cement hydration process. Am. J. Eng. Applied Sci, 9, 134-145.

Syahrullah, L. O. I., \& SINAGA, N. (2016). Optimization and prediction of motorcycle injection system performance with feed-forward backpropagation method Artificial Neural Network (ANN). American Journal of Engineering and Applied Science, 9(2), 222-235.

Taher, S. A., Hematti, R., \& Nemati, M. (2008). Comparison of different control strategies in GAbased optimized UPFC controller in electric power systems. Am. J. Eng. Applied Sci, 1(1), 45-52.
Theansuwan, W., Sriprateep, K., \& Palaprom, A. (2011, July). The biodiesel production from roast Thai sausage oil by transesterification reaction. In ITCCSCC: International Technical Conference on Circuits Systems, Computers and Communications (pp. 1-4).

Thongwan, T., Kangrang, A., \& Homwuttiwong, S. (2011). An estimation of rainfall using fuzzy setgenetic algorithms model. Am. J. Eng. Applied Sci, 4, 77-81.

Tourab, W., Babouri, A., \& Nemamcha, M. (2011). Experimental study of electromagnetic environment in the vicinity of high voltage lines. Am. J. Eng. Applied Sci, 4, 209-213.

Tsolakis, A. D., \& Raptis, K. G. (2011). Comparison of maximum gear-tooth operating bending stresses derived from niemann's analytical procedure and the finite element method. Am. J. Eng. Applied Sci, 4, 350-354.

Wang, L., Liu, T., Zhang, Y., \& Yuan, X. (2016). A methodology for continuous evaluation of cloud resiliency. Am. J. Eng. Applied Sci, 9, 264-273.

Wang, J., \& Yagi, Y. (2016). Fragment-based visual tracking with multiple representations. Am. J. Eng. Applied Sci, 9, 187-194.

Waters, C., Ajinola, S., \& Salih, M. (2016). Dissolution sintering technique to create porous copper with sodium chloride using polyvinyl alcohol solution through powder metallurgy. Am. J. Eng. Applied Sci, 9, 155-165.

Wessels, L., \& Raad, H. (2016). Recent advances in point of care diagnostic tools: A review. Am. J. Eng. Applied Sci, 9, 1088-1095.

Yeargin, R., Ramey, R., \& Waters, C. (2016). Porosity analysis in porous brass using dual approaches. Am. J. Eng. Applied Sci, 9, 91-97.

You, M., Huang, X., Lin, M., Tong, Q., \& Li, X. (2016). Preparation of LiCoMnO4 assisted by hydrothermal approach and its electrochemical performance. Am. J. Eng. Applied Sci, 9, 396405.

Zeferino, R. S., Ramón, J. R., de Anda Reyes, E., Gónzalez, R. S., \& Pal, U. (2016). Large scale synthesis of $\mathrm{ZnO}$ nanostructures of different morphologies through solvent-free mechanochemical synthesis and their application in photocatalytic dye degradation. Am. J. Eng. Applied Sci, 9, 41-52.

Zhao, B. (2013). Identification of multi-cracks in the gate rotor shaft based on the wavelet finite element method. Am. J. Eng. Applied Sci, 6, 309-319.

Zheng, H., \& Li, S. (2016). Fast and robust maximum power point tracking for solar photovoltaic systems. Am. J. Eng. Applied Sci, 9, 755-769. 
Zotos, I. S., \& Costopoulos, T. N. (2009). On the use of rolling element bearings' models in precision maintenance. Am. J. Eng. Applied Sci, 2, 344352.

Zulkifli, R., Sopian, K., Abdullah, S., \& Takriff, M. S. (2008). Effect of pulsating circular hot air jet frequencies on local and average nusselt number. American Journal of Engineering and Applied Sciences, 1(1), 57-61.

Zulkifli, R., Sopian, K., Abdullah, S., \& Takriff, M. S. (2009). Experimental study of flow structures of circular pulsating air jet. American Journal of Engineering and Applied Sciences, 2(1).
Zurfi, A., \& Zhang, J. (2016a). Model identification and wall-plug efficiency measurement of white LED modules. Am. J. Eng. Applied Sci, 9, 412-419.

Zurfi, A., \& Zhang, J. (2016b). Exploitation of battery energy storage in load frequency control-a literature survey. Am. J. Eng. Applied Sci, 9, 1173-1188.

\section{Source of Figures}

Fig. 1

https://upload.wikimedia.org/wikipedia/commons/5/5 c/Psyche_asteroid_eso_crop.jpg 